\title{
How Did Donald Trump Turn the Republican Party into the People's Party?
}

\author{
By: Kobby Barda
}

\section{Central Points}

Research Question:

Was the US election campaign a campaign based on race or stature?

\section{Findings:}

This paper examined voting patterns in US presidential election campaigns in 2016 and 2020, and compared racial voting patterns to voting patterns based on stature. The hypothesis that racial voting would act against President Trump was refuted.

\section{Meaning:}

The findings found in this research can be the start of a large voting shift in the United States, similar to the one started by President Roosevelt in 1932.

\section{Summary}

The accepted working assumption on the eve of the 2020 Presidential Election in the US was that his image, as well as the perception that he holds negative opinions regarding immigrants and immigration while supported by white supremacists, would result in voters casting their ballot based on racial or ethnic considerations to vote against him.

This paper was aimed at examining that linkage, to see if it took place in reality, or rather if voting needs to be looked at as a choice made based on class and stature, not racial background. To examine the issue at hand, 2016 voting patterns were compared to 2020 exit polls based on racial background. The findings showed that support for President Trump rose across all races, sometimes more than doubling. At the same time, votes were analyzed based on a breakdown by class. For the study, three batches of districts were chosen: the poor of America, the average of America, and the rich of America. One district was chosen from each state, and a total of 147 districts from across the US were looked at.

The research shows that as one climbs the social ladder, support for President Trump declines. Or, in the context of this paper: the lower one is on the social class ladder, especially among the 'forgotten' periphery, the higher the approval and support rate of President Trump is. 


\section{$\underline{\text { Results }}$}

$\checkmark$ Ethnicity: The results show an increase in support for Trump across all ethnicities in the US during the 2020 election compared to 2016: Muslims $+337 \%$; Indian $+75 \%$; Asian $+66.7 \%$; African American $+50 \%$, Latino $/$ Hispanic $+14.29 \%$; White $+7.41 \%$.

$\checkmark$ Social Class: The results show a different voting pattern based on social classes across the US:

- Rich America - 41 of the 49 richest counties saw Trump lose support.

- Average American - 15 counties saw a decline in support, one had no change, and Trump's support increased in 33 of the 49 counties.

- Poor America - 40 of the 49 poorest counties saw Trump gain support, while he lost support in six counties and two remained unchanged. 


\section{How Did Donald Trump Turn the Republican Party into the People's Party?}

In the days ahead of the 2020 Presidential Election, commentators dealt intensely with the question of racial motivation, which was meant to determine the outcome. The assumption was that angry ethnic minorities would look to repay Trump and decide the fate of the 2020 campaigns. The rationale was as follows: in 2016, many of these minorities chose not to partake in the democratic process, and by sitting out, they allowed Trump to enter the White House. Op-ed headlines, including an AP one titled "Election emerges as referendum on race relations in America," placed Trump's apparent promotion of racism in the spotlight. The University of Berkley's blog interviewed faculty members on this topic. The post headline read: "Election 2020: A referendum on racial justice in America.",

"In this election, Trump has decided to attack Black people directly. He has decided to deploy the military in response to a movement that is expressing grievances about historical and present anti-Black racism. He has tried to win over white voters by claiming that Black people are going to take over the suburbs," Professor of law Khiara M. Bridges said in the article. "He is doing the same thing that his attacks on Mexican people did in 2016, the same thing that his attacks on Muslim people did in 2016. He is attempting to exclude from the body politic_-exclude from what is imagined as American-all things that are not white."

Professor Russell Robinson, also from Berkley's Law Department and the Faculty Director, Center on Race, Sexuality \& Culture, described what the elections were about: "We're at a turning point, and the hope that I have and the people in my community have, which includes anti-racist White folks and anti-racists who are Latinx and Asian American, and of course, Black folks, is that the country will repudiate Trump and his white nationalist project."

Professor Patrick Naranjo, The American Indian Graduate Program (AIGP) Director, said the following: "It's going to be a difficult process, but I actually feel that we are at that moment where folks want to see change. A lot of people are tired of having to navigate or interpret that specific history that was created from some of these institutional, or colonial—maybe just, say, old procedures and processes that have brought us to this moment of frustration... These are some of the common conversations that we're having with things like native identity, immigration, social justice, unrest from Black Lives Matter."

There are a range of explanations to the fact that so many people believed the 2020 campaign would revolve around racial tensions in the US. The most central one might be the COVID-19 pandemic and ensuing crisis, and its effects on various populations. An October New York Times editorial titled "After a summer of racial reckoning, race is on the ballot" analyzed the factors which caused social unrest in America as a catalyst for the public's mobilization to vote on certain issues: "Hoping to harness the energy at

1 KAT STAFFORD, Election emerges as referendum on race relations in America, apnews.com, October 30, 2020, Available at https://apnews.com/article/us-elections-race-relationsdf0d291209081985cbea6ac050e1fff8, [Accessed at November, 19, 2020].

${ }^{2}$ Edward Lempinen, Election 2020: A referendum on racial justice in America, news.berkeley.edu, NOVEMBER 2, 2020, Available at https://news.berkeley.edu/2020/11/02/election-2020-areferendum-on-racial-justice-in-america/ , [Accessed at November, 19, 2020]. 
demonstrations amid a national conversation about race, organizers pushed massive voter registration drives over the summer. The Movement for Black Lives, a coalition of activist groups, hosted a series of virtual town halls and conventions focused on election issues. And local chapters of Black Lives Matter hosted Instagram live chats with candidates to weigh their positions on issues of race and policing."3

Many of those leading the Black Lives Matter (BLM) movement were quoted before the elections as intentionally steering the conversation to the point at which the elections would pose race, and systemic or institutionalized racism, as the key question voters need to answer.

For example, LaTosha Brown, co-founder for Black Voters Matter Fund was quoted by $A B C$ News as saying: "The Black community is fed up with the state-sanctioned violence, the police brutality, and violence against the community. The folks that we're talking to, they are looking for a radical transformation of how policing takes place in this country, and they want to see changes in the criminal justice system, which has exploited and devastated our community."

However, African Americans were not the only ones looking at race as the key element to mobilize voters. Also Muslim activists, including those who created the \#MyMuslimVote hashtag, wanted to get people to vote against a president viewed as Islamophobic. This was captured in an article titled: "Trump's travel ban and Islamophobia could drive a record turnout of Muslims in the US election." 5

The piece frames the racial issue as "prevailing concerns over Islamophobia and Mr. Trump's so-called Muslim travel ban-an executive order banning foreign nationals from some predominantly Muslim countries from visiting the US-are understood to be significant factors motivating stronger engagement." Mr. Ishraq Ali of the MPower Change organization, said "Islamophobia and anti-Muslim bias, white nationalism-many members in the community are observing and witnessing this." Therefore, he added, they were registering and mobilizing people to vote. The understanding Trump was supposed to take a hit during the 2020 elections was also obvious in Mehmet Ozalp's piece, "Who will Muslim Americans vote for in the US elections?" Ozalp, the Director of The Centre for Islamic Studies and Civilization and Executive Member of Public and Contextual Theology at Charles Sturt University, wrote:

It is unclear if Trump's poor handling of the pandemic has caused a decline in Muslim support for Trump. But two other actions of his still concern Muslim voters. The first is the 2017 Executive Order 13769 that banned Muslims from seven countries-Iraq, Syria, Sudan, Iran, Yemen, Libya and Somalia-from

\footnotetext{
${ }^{3}$ After a summer of racial reckoning, race is on the ballot, nytimes.com, October 30, 2020, Available at https://www.nytimes.com/2020/10/30/us/racial-justice-elections.html, [Accessed at November, 19, 2020].

${ }^{4}$ Averi Harper and Briana Stewart, How racial issues will define the 2020 presidential election, abcnews.go.com, 18 August 2020, Available at https://abcnews.go.com/Politics/racial-issues-define2020-presidential-election/story?id=72394595, [Accessed at November, 19, 2020].

${ }^{5}$ TOM STAYNER, \#MYMuslimVote: Trump's travel ban and Islamophobia could drive a record turnout of Muslims in the US election, sbs.com.au, Oct. 31, 2020, Available at: https://www.sbs.com.au/news/mymuslimvote-trump-s-travel-ban-and-islamophobia-could-drive-arecord-turnout-of-muslims-in-the-us-election, [Accessed at November, 19, 2020].
} 
entering the United States on grounds that these states were supporting terrorism. The order also indefinitely suspended entry to the US for all Syrian refugees. The executive order came to be known as the "Muslim ban" and was criticized for targeting Muslims "because of their faith". The ban had a huge impact on the freedom of travel for many Muslim Americans who were not citizens. The second was the 2018 move of the US embassy in Israel to Jerusalem, in effect recognizing Jerusalem as a Jewish capital. This infuriated Palestinians and Muslims around the world. ${ }^{6}$

\section{Race-based Voting Patterns in the US}

At the time this article is being written, not all the data is available on individuals' vote counting. Yet, the goals were to try and bring the information as close as possible to Election Day. Therefore, comparative attempts were done using existing data from various think tanks using the 2016 election data, compared to the networks' 2020 exit polling data. It is important to stress that the significant increase in the use of mail-in ballots might create a larger deviation than normal in the exit polls.

\section{The Muslim Voice in America}

2016: According to PEW estimates, the 2016 elections saw $8 \%$ of Muslims vote for Donald Trump, while Hillary Clinton received the support of $78 \%$ of Muslim voters. ${ }^{7}$

2020: Information is based on a survey by Chicago University's NORC Institute for the Associated Press, featuring over 110,000 respondents from around the US. In this survey, $35 \%$ of Muslim voters supported Trump, compared to $64 \%$ voting for Joe Biden. ${ }^{8}$ These numbers are especially surprising, when they are seen on the backdrop of a 2017 PEW survey which found that 2 of 3 Muslims identity as Democrats. ${ }^{9}$

According to this, there is a $337 \%$ increase in the support for Trump since 2016 , andwhen looking at the 2018 data-an increase of $169 \%$ since 2018.

\footnotetext{
${ }^{6}$ Mehmet Ozalp, Who will Muslim Americans vote for in the US elections?, theconversation.com, Available at: https://theconversation.com/who-will-muslim-americans-vote-for-in-the-us-elections146854, October 27, 2020, [Accessed at November, 19, 2020].

${ }^{7}$ U.S. Muslims Concerned about Their Place in Society, but Continue to believe in the American Dream, pewforum.org, JULY 26, 2017, Available at: https://www.pewforum.org/2017/07/26/findings-frompew-research-centers-2017-survey-of-us-muslims/ [Accessed at November, 9, 2020].

${ }^{8}$ U.S. Muslims Concerned about Their Place in Society, but Continue to believe in the American Dream, pewforum.org, JULY 26, 2017, Available at: https://www.pewforum.org/2017/07/26/findings-frompew-research-centers-2017-survey-of-us-muslims/ [Accessed at November, 9, 2020].

${ }_{9}$ MICHAEL LIPKA, U.S. Muslims see their relationship with Trump as strained, pewresearch.org, JULY 27, 2017, Available at: https://www.pewresearch.org/fact-tank/2017/07/27/u-s-muslims-see-theirrelationship-with-trump-as-strained/ ,[Accessed at November, 9, 2020].
} 


\section{The Indian Vote in America}

2016: Based on the AAPI DATA estimates, some four million Americans of Indian descent live in the US. Of them, some $16 \%$ voted for Trump while $76 \%$ supported Clinton. ${ }^{10}$

2020: In the 2020 Presidential Elections, Kamala Harris was the Democratic vicepresidential nominee. Her mother had immigrated to the US from India. Despite this fact, which should have helped preserve the Indian vote, AAPI DATA shows an increase of support in Trump, with $28 \%$ voting for him, and the Biden-Harris ticket getting only $66 \%$ of the vote. ${ }^{11}$

The Afro-American Vote

2016: Hillary Clinton won an impressive $88 \%$ of votes, while only $8 \%$ were given to Trump. ${ }^{12}$

2020: Based on NBC's exit poll, President Trump increased his support among AfroAmericans by $50 \%$, bringing it to $12 \%$ of Afro-American voters supporting Trump. ${ }^{13}$ Biden received the remaining $88 \%$.

The Hispanic/Latino Vote

2016: According to PEW, Hillary Clinton won $66 \%$ of the Hispanic vote, while Trump received $28 \%$ of the vote. ${ }^{14}$

2020: According to the NBC exit poll, President Trump gained 32\% of the Hispanic vote, an increase of over $14 \%$ compared to the 2016 elections. Biden received $65 \%$ of the vote.

\section{$\underline{\text { Asian American Vote }}$}

2016: Based on data from the Asian American Legal Defense and Education Fund (AALDEF), 18\% of the Asian American vote went to Trump in 2016, while Clinton won $79 \%$ of it. ${ }^{15}$

10 KARTHICK RAMAKRISHNAN, Trump Faces Uphill Climb among Indian Americans, aapidata.com, JUNE 26, 2017, Available at: http://aapidata.com/blog/trump-indian-americans/, [Accessed at November, 9, 2020].

${ }^{11}$ An Indian American perspective on US Election 2020, iglobalnews.com, 03 Nov, 2020, Available at: https://www.iglobalnews.com/newsviews/an-indian-american-perspective-on-us-election-2020, [Accessed at November, 9, 2020].

12 JENS MANUEL KROGSTAD AND MARK HUGO LOPEZ, Black voter turnout fell in 2016, even as a record number of Americans cast ballots, pewresearch.org, MAY 12, 2017, Available at: https://www.pewresearch.org/fact-tank/2017/05/12/black-voter-turnout-fell-in-2016-even-as-arecord-number-of-americans-cast-ballots/ , [Accessed at November, 9, 2020].

13 Exit Polls 2020, CNBC.COM, Nov. 3, 2020, Available at: https://www.nbcnews.com/politics/2020elections/exit-polls, [Accessed at November, 11, 2020].

14 JENS MANUEL KROGSTAD AND MARK HUGO LOPEZ, Hillary Clinton won Latino vote but fell below 2012 support for Obama, pewresearch.org, Available at: https://www.pewresearch.org/facttank/2016/11/29/hillary-clinton-wins-latino-vote-but-falls-below-2012-support-for-obama/, [Accessed at November, 11, 2020].

${ }^{15}$ New AALDEF Report: The Asian American Vote in 2016, aaldef.org, April 18, 2017, Available at: https://www.aaldef.org/press-release/new-aaldef-report-the-asian-american-vote-in-2016/,

[Accessed at November, 11, 2020]. 
2020: According to data from the same research institute, the AALDEF, exit polls showed trump winning 30\% of the Asian American vote in 2020, a 66.67\% increase. Biden received $67 \%$ of the vote in this community. ${ }^{16}$

The 'White' Vote

Trends show that also among the so-called 'white voters,' Trump managed to increase his support. This was the key populace in his 2016 surprise presidential victory.

2016: According to PEW, Trump won an overall 54\% of the white vote in America. When broken down, it was apparent men supported him more than women: $62 \%$ of white American men, and $47 \%$ of white American women. Clinton received over $34 \%$ of the white vote, with $32 \%$ support among white men and $46 \%$ from white women. ${ }^{17}$

2020: NBC's exit poll marked Trump as winning $58 \%$ of the white vote, with $61 \%$ of white men voting for him alongside $55 \%$ white women. Biden, on the other hand, won $41 \%$ of the white vote, taking $38 \%$ of white men's votes and $44 \%$ of white women's.

The conclusion arising from all these parameters is that not only is Donald Trump not losing votes because of their racial identity, but is actually increasing his performance and support across all races in America. Messages about these communities becoming antiTrump bastions, as detailed in countless published pieces in the academic papers and popular press, simply did not materialize in the 2020 presidential election. Moreover, President Trump became the candidate to capture the largest portion of Republican nonwhite voters since $1960 .{ }^{18}$

As of today, the electorates have not yet finalized the vote; however, based on the counting, it appears Joe Biden will be the $46^{\text {th }}$ President of the United States. However, if all the defined racial voting patterns (the indexing did not include terms like 'other' or 'multiracial') demonstrated an increase in the support towards the incumbent president, and weren't the main voting issue, what can be the alternative explanation? What is the question dividing America, and what was the 2020 election actually about?

\section{The 'Big Tent' Coalitions of Roosevelt and Trump}

During the 1930s, the US was recuperating from the Great Depression. The 1932 Democratic presidential candidate, Franklin D. Roosevelt (FDR), introduced a new strategy of targeting voters. The idea was to introduce a long-term electoral shift, which would rely on a winning coalition of blue-collar workers, minorities, and residents of the southern states. This strategy not only won the 1932 election, it also altered traditional voting patterns in the Democratic Party up to that date. According to David Hopkins, it was Roosevelt who created the new reality. "The New-Deal coalition, constructed under

\footnotetext{
16 Preliminary 2020 Asian American Exit Poll results; Asian American voter problems, aaldef.org, November 4, 2020, Available at: https://www.aaldef.org/press-release/preliminary-asian-americanexit-poll-results-for-2020-elections/, [Accessed at November, 11, 2020].

17 An examination of the 2016 electorate, based on validated voters, pewresearch.org, AUGUST 9, 2018, at: https://www.pewresearch.org/politics/2018/08/09/an-examination-of-the-2016-electoratebased-on-validated-voters/, [Accessed at November, 11, 2020].

18 Zachary Evans, Trump Won Highest Share of Non-White Vote of Any Republican Since 1960, Exit Polls Show,yahoo.com, November 4, 2020, , Available at https://news.yahoo.com/trump-wonhighest-share-non-164843048.html, [Accessed at November, 24, 2020].
} 
the big tent of the Democratic Party in 1932, is what gave President Roosevelt four terms in office and created a long-term hold in Congress. The coalition is described as an alliance of 'the socially deprived' - the poor people in the cities, the working class, union members, Catholics and Jews, farmers, African-Americans from the North and White from the South-united under one objective and a demand for Federal action during a period of financial catastrophe."19

What is interesting and defining of this alliance, is that it is an alliance of people with a certain economic standing, and this is the glue holding people from different backgrounds, upbringings, and races together, as described by Richard Viguerie:

"This 'big tent' approach is exactly what kept the Democrats in power for so long. FDR's coalition brought together people who felt very uncomfortable being in the same room as each other-white Dixiecrats, Jews and blacks, farmers and university intellectuals."20 Overall, it was FDR who, in 1932, cast the foundation connecting everything. Alan Hickord defined it well: "Franklin D. Roosevelt put together the coalition of overlooked and forgotten minorities that is still an important part of the Democratic Party."21

At President Trump's Inauguration Ceremony, on November 9, 2016, he pledged the "forgotten men and women of our country will be forgotten no longer." 22 It was no accident the phrase "forgotten men" was used. In fact, Trump decided to use Roosevelt's wording, who coined the phrase as the reason for rebuilding the economy from the bottom up. The term forgotten man was first introduced in a 1932 speech by FDR, in a pledge Amity Shlaes described as follows: "If elected, Roosevelt promised, he would act in the name of 'the forgotten man at the bottom of the economic pyramid'."23 To do so, Shlaes continues, Roosevelt found ways to provide them with federal budgets.

Another common line can be found in the way the party establishment looked at steering the ship towards the bottom of the economic pyramid. FDR, who coined this phrase in his famous 1932 radio address, caused an uproar among many in his party who thought such a pivot would lead to clashes between classes in America. He believed that the party's future should be redesigned so that it would rely upon "the forgotten, the unorganized but the indispensable units of economic power which exists in America's working class."24

According to Barry Eidlin, Roosevelt managed to use the Great Depression as a tool to mobilize people from lower classes, through the term "forgotten men". "FDR appealed to

19 David A. Hopkins, Red Fighting Blue: How Geography and Electoral Rules Polarize American Politics, New York, NY, Cambridge University Press, 2017.P-71. [Translated back from Hebrew]

${ }^{20}$ Richard A. Viguerie, Conservatives Betrayed: How George W. Bush and Other Big Government Republicans Hijacked the Conservative Cause, Bonus Books, Los-Angeles-CA, 2006.P-190.

${ }^{21}$ Alan G. Hickrod, An embattled and unapologetic liberal, New York- NY, iUniverse, 2005.P-38.

22 Transcript: Donald Trump's Victory Speech, New-York Times, NTTIMES.COM, Nov. 9, 2016, Available at: https://www.nytimes.com/2016/11/10/us/politics/trump-speech-transcript.html, [Accessed at November, 24, 2020].

${ }^{23}$ Amity Shlaes, The forgotten man: a new history of the Great Depression, New York-NY, Harper Perennial, 2008.

24 JEFFERSON COWIE, Donald Trump and History's Competing Visions of America's 'Forgotten Man, time.com, Available at: https://time.com/4567949/forgotten-man-donald-trump/, [Accessed at November, 24, 2020]. 
the working class and positioned the Democratic Party as the 'natural' home for those voters. In turn, the working class identified with the Democratic Party as their party, and they saw in Roosevelt a 'friend and protector' and voted accordingly."25

Trump, who followed FDR in this context, tried to repeat what was successfully demonstrated in the 1930 s of the $20^{\text {th }}$ Century. Ben Bradlee outlined the similarities in the strategy chosen by Trump to captivate the votes of the lower echelons: "The loss of five million manual jobs since 2000, along with stagnation in wages, caused anger to boil. The power of talk shows on the radio, TV networks and the rising power of social networks, helped Trump's 'Make America Great Again' campaign, alongside the nostalgia of 'reuniting the base' of [Republican] voters. As to Trump's statement about the 'forgotten men'-it was an attempt to echo Roosevelt's 1932 message about the forgotten men at the bottom of America's economic and social pyramid."26

The element of caring for the forgotten people took an important place also in Trump's speech from January 2017. At the start of that address he said: "January 20th 2017, will be remembered as the day the people became the rulers of this nation again. The forgotten men and women of our country will be forgotten no longer. Everyone is listening to you now. You came by the tens of millions to become part of a historic movement the likes of which the world has never seen before." He then continued, and went on to end his speech by saying the following: "So to all Americans, in every city near and far, small and large, from mountain to mountain, and from ocean to ocean, hear these words. You will never be ignored again. Your voice, your hopes, and your dreams, will define our American destiny [...] Together, We Will Make America Great Again."27

\section{On the Growing Gap between Classes in America}

Recent years have seen the gaps between classes in America brought to a new resolution. The dividing line is no longer geographic, or "Red States" versus "Blue States," but rather Rural America versus Urban and Suburban America. Also the stats still defined by their political colors, when one looks closely, can be broken down by this paradigm; usually, the Blue States feature large, influential urban and suburban centers, while Red States have more of a rural influence and impact.

Comparing the 2020 Presidential Results between the largest Republican state-Texasand the largest Democratic one-California_-shows how the blue color splashes in urban centers compare to the red rural areas.

25 Barry Eidlin, Labor and the Class Idea in the United States and Canada, New York-NY, Cambridge University Press, 2018.P-168. [Translated back from Hebrew]

26 Ben Bradlee Jr, The Forgotten: How the People of One Pennsylvania County Elected Donald Trump and Changed America, New York-NY, Hachette, 2018.

${ }^{27}$ The Inaugural Address, whitehouse.gov, January 20, 2017, Available at https://www.whitehouse.gov/briefings-statements/the-inaugural-address/, [Accessed at November, 24, 2020]. 
California

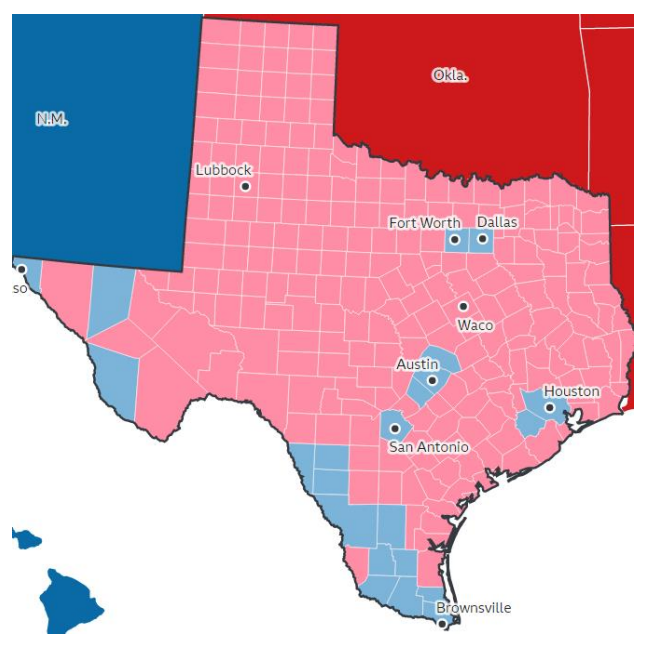

Texas

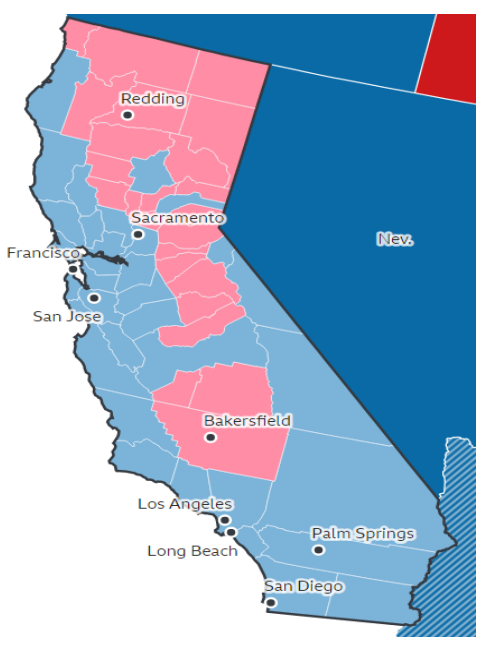

It is not coincidence that Trump speaks of those areas as "forgotten men and women," the people society ignores, in a world changing the way it manufactures, shops, invents, and acts. A report by the US Chamber Technology Engagement Center from March 2019 found that "Rural America comprises over 18 million households and over 37 million adults. While accounting for nearly $15 \%$ of the adult population and covering over $72 \%$ of the land, annual revenues of businesses located in rural areas make up less than $10 \%$ of the U.S. economy (approximately $\$ 3.1$ trillion). Due to lack of opportunities, a large portion of rural residents have been migrating to urban areas for new or better jobs. Currently, about 17.5 million rural adults (over $47 \%$ ) are either unemployed or are not actively looking for jobs." 28

Over the years and under the auspices of various international agreements and treaties, such as the North America Free Trade Agreement (NAFTA) between the US, Canada, and Mexico, a large part of the American industrial segment, those producing "made in the USA" products, found itself crossing the border and manufacturing at a cheaper cost. The automobile industry is a leading example of this. In 2017, the Department of Agriculture's Economic Research Service published a report titled Rural Manufacturing Survival and Its Role in the Rural Economy. This paper analyzed the field between 2000 and 2015 , finding a decrease of $30 \%$ in the number of people employed in manufacturing. ${ }^{29}$ The report notes that, "Manufacturing provides more jobs and higher earnings in rural areas than many other sectors, including agriculture and mining. Manufacturing is also relatively more important to the rural economy than to the urban economy. Between 2001 and 2015, a period that included the 2001 and 2007 - 09 recessions, manufacturing

${ }^{28}$ Unlocking the Digital Potential of Rural America, americaninnovators.com, March 2019, Available at americaninnovators.com/wp-content/uploads/2019/03/Unlocking-the-Digital-Potential-of-RuralAmerica.pdf, [Accessed at November 24, 2020].

${ }^{29}$ Sarah A. Low, Rural Manufacturing Survival and Its Role in the Rural Economy, usda.gov, October 25, 2017, Available at https://www.ers.usda.gov/amber-waves/2017/october/rural-manufacturingsurvival-and-its-role-in-the-rural-economy/, [Accessed at November, 24, 2020]. 
employment fell by close to 30 percent, however. Because of manufacturing's prevalence in rural America, this decline hit rural areas disproportionately hard."

Unfortunately, this issue is not relevant only to manufacturing and agriculture, but also to trade in those same areas. A report by the State of Minnesota found that "rural grocery store owners want to pass the baton to a new generation. In fact, 63 percent of store owners said they do not intend to own their store 10 years from now. But these intentions haven't resulted in plans. In fact, a large percentage of respondents said they do not have a plan to transition their business." Without a generation to continue the business, the report describes a situation in which, "over the past three years, 1,210 businesses responded to our survey question about succession planning, and 38 percent reported having no succession plan in place."30

The problem is especially astute considering the engine driving the American economy, the high-tech industry, is absent in those rural areas of the US. One of the important reasons for this absence, and for the absence of better paying jobs, is the lack of proper cellular infrastructure. In 2016, the Federal Communications Commission (FCC) reported that $39 \%$ of rural Americans lacked access to high-speed internet, compared to $6 \%$ of urban Americans. ${ }^{31}$ One of the first tasks taken up by President Trump was the creation of a special taskforce to deal with this issue. ${ }^{32}$ In October 2017, the Presidential task force for agriculture and rural prosperity identified the electronic connectivity of rural areas as a foundation for further developing agriculture, economic growth, job options, infrastructure, technological innovations, security, energy, and quality of life for the peripheral part of the US. According to a report by the Delloite consulting company, "This finding prompted the creation of the American Broadband Initiative, an effort by cabinet agencies to support private sector expansion of rural broadband and effectively steward federal tax dollars in that partnership. This is an important step, but it alone won't create smart rural communities." 33

All of these explanations create demographic changes in which the younger generation leave the periphery and migrate to the cities, leaving behind them an older population. One of five elderly Americans lives in rural areas, many of which are in states where over half their elderly population is in the rural part of the state. A report by the US census sampling

30 The future of rural grocery stores, extension.umn.edu, Available at: https://extension.umn.edu/vital-connections/future-rural-grocery-stores, [Accessed at November, 24, 2020].

${ }^{31} 2016$ Broadband Progress Report, fcc.gov, January 29, 2016, , Available at: www.fcc.gov/reportsresearch/reports/broadband-progress-reports/2016-broadband-progress-report , [Accessed at November, 24, 2020].

32 Presidential Executive Order on Promoting Agriculture and Rural Prosperity in America, whitehouse.gov, April 25, 2017, Available at: https://www.whitehouse.gov/presidentialactions/presidential-executive-order-promoting-agriculture-rural-prosperity-america/ , [Accessed at November, 24, 2020].

${ }^{33}$ The promise of smart rural communities, www2.deloitte.com, 27 September 2019, Available at: https://www2.deloitte.com/us/en/insights/industry/public-sector/the-promise-of-smart-ruralcommunities.html , [Accessed at November, 24, 2020]. 
the elderly population in rural America between 2012 and 2016 found that $17.5 \%$ of the rural population was 65 or older, compared to only $13.8 \%$ of the urban population. ${ }^{34}$

The troubling situation in which the periphery is forgotten and left behind takes its toll in the forms of addiction and suicide. Narcotic drugs, also known as opioids, are a serious problem among rural residents. According to the Center for Disease Control (CDC), opioids-including prescription painkillers, heroin, and others-killed over 42,000 people in 2016, more than any previous year in history, and a higher rate was found in rural areas. ${ }^{35}$ A survey done for the AFBA and National Farmers Union (NFU) found that three of four farmers and agricultural workers $(74 \%)$ were directly affected by the use of opioids, either by using them themselves or knowing a family or relative who had. ${ }^{36}$ Research published in 2019 by Daniel Steelesmith on suicides in the US between 1999 and 2016 showed that "Suicide rates were higher and increased more rapidly in rural than in large metropolitan counties. The highest deprivation quartile was associated with higher suicide rates compared with the lowest deprivation quartile, especially in rural areas."37

It is important to stress that the term "periphery" must also be addressed as certain parts of the urban landscape. The term "inner city," used to describe failing neighborhoods (especially from weakened or immigrant communities, including Afro-Americans), has similar lines and parallels as the differences between the urban and rural we are focusing on.

\section{Was the 2020 Presidential Election Around Class?}

\section{Research methodology}

The first part of this paper described the pre-election predictions, with the understanding Trump's presidency — seen as racist-promoted white supremacy, the persecution of immigrants in general, and Mexicans in particular, hurt the entrance of Muslims to America, and singled out Asians, including the nicknaming of the COVID-19 pandemic the "Chinese Virus." This assumption was refuted at the balloting stations. While most minority members voted for Joe Biden, across the board the support for Trump grew among the various ethnic minorities in the US.

In the second part of this essay, I revisited the historical roots and the last time a significant electoral base was created regarding America's forgotten people (by Franklin D. Roosevelt in 1932), and looked at the similarities adopted by Trump during his term in office. The third part is dedicated to understanding the core issues of the class and geographical

\footnotetext{
${ }^{34}$ AMY SYMENS SMITH AND EDWARD TREVELYAN, In Some States, More Than Half of Older Residents Live In Rural Areas, census.gov, OCTOBER 22, 2019, Available at:

https://www.census.gov/library/stories/2019/10/older-population-in-rural-america.html , [Accessed at November, 24, 2020].

${ }^{35}$ Opioid Overdose, cdc.gov. Available at: https://www.cdc.gov/drugoverdose/index.html , [Accessed at November, 25, 2020].

${ }^{36}$ Rural Opioid Epidemic, fb.org, Available at: https://www.fb.org/issues/other/rural-opioidepidemic/, [Accessed at November, 25, 2020].

37 Danielle L. Steelesmith, Contextual Factors Associated with County-Level Suicide Rates in the United States, 1999 to 2016, jamanetwork.com, September 6, 2019, Available at:

https://jamanetwork.com/journals/jamanetworkopen/fullarticle/2749451, [Accessed at November, 25, 2020].
} 
periphery in the US, as a step towards understanding how, in essence, the 2020 presidential election was split by class.

The way the statistics were gathered included data mining from 49 districts, representing one district in each state. Since the District of Columbia is composed of a single voting area, and there is not a proper correspondence between Alaska's voting districts and physical ones, these two were left out of the process. The information was gathered from a report by the USA Today newspaper, based on three categories: the 49 richest districts, ${ }^{38}$ the 49 poorest ones, ${ }^{39}$ and the 49 most average districts in the US. To create the average district list, an index was created based on average income and matching them with those with the income closest to it, as reported by the Agriculture Department, as well as through the information available from the average income report of $2018 .{ }^{40}$

The Demographic data was compiled and completed based on the central census website. ${ }^{41}$ Collecting data for each district sampled the total of votes given in 2016 and 2020 to Donald Trump, the percentage of the vote he received from all of society, and the difference in voting percentages. A rise in the percentage and the actual number of voters was painted green; a rise in voters but decrease in the percentage was painted orange; and a decrease in both percentage and actual voters was marked in red. Districts without significant change were painted gray, and districts which flipped from Republican to Democrat were painted blue (this is all illustrated in the chart):

\begin{tabular}{|c|c|c|c|}
\hline Color & $\begin{array}{c}2020 \text { total vote } \\
\text { increase }\end{array}$ & $\begin{array}{c}2020 \\
\text { percentage } \\
\text { increase }\end{array}$ & $\begin{array}{c}\text { Flipped } \\
\text { Democrat }\end{array}$ \\
\hline & $\mathrm{V}$ & $\mathrm{V}$ & \\
\hline & $\mathrm{X}$ & $\mathrm{V}$ & \\
\hline & $\mathrm{Tie}$ & $\mathrm{V}$ & \\
\hline & $\mathrm{X}$ & $\mathrm{X}$ & \\
\hline & & & $\mathrm{V}$ \\
\hline
\end{tabular}

In each of the districts data was collected from dominate ethnic groups (Asians weren't sampled in the 'poor' areas and native Americans weren't sampled in the 'rich' ones because they are marginal).When there was lacking data or none at all, the field was left empty.

Before analyzing the districts themselves, it is important to remember that the 2020 election was marked as the largest in history, with 159.8 million voters. A total of $66.8 \%$

38 Grant Suneson, Richest counties in the US: A state-by-state look at where median household income exceeds norm, usatoday.com, Jan. 24, 2019. , Available at:

https://www.usatoday.com/story/money/2019/01/24/richest-counties-us-median-householdincome/38870227/, [Accessed at November, 25, 2020].

39 Samuel Stebbins, Poorest counties in the US: A state-by-state look at where median household income is low, usatoday.com, Jan. 25, 2019. Available at:

https://www.usatoday.com/story/money/2019/01/25/poorest-counties-in-the-us-medianhousehold-income/38870175/, [Accessed at November, 25, 2020].

${ }^{40}$ County-level Data Sets, economic research service U.S department of Agriculture, www.ers.usda.gov, Available at:

https://data.ers.usda.gov/reports.aspx?ID=17828\#P86a11fe8079e42679d8fcca5fd90212f 34 148iT1, [Accessed at November, 25, 2020].

41 www.census.gov 
of the eligible voters cast their ballots — the highest percentage since the 1900 presidential election. ${ }^{42}$

\section{Analyzing the Richest Districts in America}

An in-depth look at the 49 richest districts in the US shows that while Trump increased the absolute number of votes in all districts, he increased his share and percentage in only eight of them. This happened in four Democratic states: California (Santa Clara County), Hawaii (Honolulu County), Nevada (Elko County), and New Mexico (Alamos County) as well as four Republican ones: Idaho (Ada County), Montana (Richland County), North Dakota (Williams County), and Utah (Summit County). An interesting data point is found in California and Hawaii, where Trump's relative support grew in districts with a significant Asian-American population (39\% and $42.9 \%$, respectively).

In 40 other districts, Trump saw a decline in the percentage of voters supporting him in 2020 compared to 2016 . In total, this is a drop in support in over $81 \%$ of the sampled rich districts across the US.

Four of the rich districts saw their color change, as Biden won them in 2020 after Trump won them in 2016. In Arizona (Maricopa County), Trump received 1.1\% less of the vote than the previous election. This was part of a state-wide trend, which saw the entire statenot only the county—vote for Biden. In Illinois (Kendall County), he received 1.5\% less of the vote; in Kansas (Johnson County), a Republican state both in 2016 and 2020, he received 2.9\% less of the vote, and in New Hampshire (Rockingham County), and he received $1.5 \%$ less than in the 2016 presidential election.

Overall, Trump saw an average decrease of $4.08 \%$ in votes in the rich counties, compared to what he received in the same 49 counties in the 2016 elections.

42 Hannah Miao, 2020 election sees record high turnout with at least 159.8 million votes projected, cnbc.com, NOV 4, 2020. Available at: https://www.cnbc.com/2020/11/04/2020-election-sees-recordhigh-turnout-with-at-least-159point8-million-votes-projected.html, [Accessed at November, 25,

2020]. 


\begin{tabular}{|c|c|c|c|c|c|c|c|c|c|c|c|}
\hline State & District & 2020 Votes for Trump & 2020 Perc & 2016 Vote 2 & 2016 Perc $F$ & Percentag, & African-A & White \% & Hispanic ? & Asian \% & Avg. Income \\
\hline Alabama & Shelby County & 79,428 & $69 \%$, & 72846 תו & $73.40 \%$ & $-4.40 \%$ & $13.30 \%$ & $82.50 \%$ & $5.80 \%$ & $2.30 \%$ & $\$ 74,063$ \\
\hline Arizona & Maricopa County & 995,665 & $48 \%$ & 590,465 & $49.10 \%$ & $-1.10 \%$ & $6.40 \%$ & $82.80 \%$ & $31.40 \%$ & $4.60 \%$ & $\$ 58,580$ \\
\hline Arkansas & Benton County & 73,965 & $62 \%$ & 60,751 & $62.90 \%$ & $-0.90 \%$ & $2.10 \%$ & $88.50 \%$ & $17.10 \%$ & $4.20 \%$ & $\$ 61,271$ \\
\hline California & Santa Clara County & 214161 Counted $(95 \%)$ & $25 \%$ & 137,452 & $20.90 \%$ & $4.10 \%$ & $2.80 \%$ & $52.40 \%$ & $25.00 \%$ & $39.00 \%$ & $\$ 106,761$ \\
\hline Colorado & Douglas County & 121,270 & $52 \%$ & 100,178 & $54.80 \%$ & $-2.80 \%$ & $1.70 \%$ & $89.50 \%$ & $9.10 \%$ & $5.40 \%$ & $\$ 111,154$ \\
\hline Coneticut & Fairfield County & 168,499 & $36 \%$ & 155,457 & $37.90 \%$ & $-1.90 \%$ & $12.90 \%$ & $60.90 \%$ & $20.50 \%$ & $5.40 \%$ & $\$ 89,773$ \\
\hline Delaware & New Castle County & 88,364 & $31 \%$ & 85,507 & $32.70 \%$ & $-1.70 \%$ & $26.40 \%$ & $56.30 \%$ & $10.40 \%$ & $5.90 \%$ & $\$ 68,336$ \\
\hline Florida & St. Johns County & 110,946 & $63 \%$ & 88,633 & $65.00 \%$ & $-2 \%$ & $5.60 \%$ & $81.90 \%$ & $7.50 \%$ & $3.30 \%$ & $\$ 73,640$ \\
\hline Georgia & Forsyth County & 85,142 & $66 \%$ & 69,801 & $71.70 \%$ & $-5 \%$ & $4.40 \%$ & $69.00 \%$ & $9.70 \%$ & $15 \%$ & $\$ 96,445$ \\
\hline Hawaii & Honolulu County & 136,259 & $36 \%$ & 84,142 & $31.70 \%$ & $4.30 \%$ & $2.80 \%$ & $17.90 \%$ & $10.00 \%$ & $42.90 \%$ & $\$ 80,078$ \\
\hline Idaho & Ada County & 130,699 & $50 \%$ & 93,748 & $47.90 \%$ & $2.10 \%$ & $0.65 \%$ & $92.86 \%$ & $4.48 \%$ & $1.74 \%$ & $\$ 60,151$ \\
\hline Illinois & Kendall County & 29492 Counted $(95 \%)$ & $46 \%$ & 24,152 & $47.50 \%$ & -1.5 & $8.00 \%$ & $67.40 \%$ & $20.00 \%$ & $3.30 \%$ & $\$ 89,860$ \\
\hline Indiana & Hamilton County & 101,587 Counted $(95 \%)$ & $52 \%$ & 87,299 & $56.80 \%$ & $-4.80 \%$ & $4.50 \%$ & $82.80 \%$ & $4.30 \%$ & $6.50 \%$ & $\$ 90,582$ \\
\hline lowa & Dallas County & 27928 Counted ( $95 \%)$ & $50 \%$ & 19,288 & $51.30 \%$ & $-1.30 \%$ & $2.60 \%$ & $84.60 \%$ & $6.30 \%$ & $5.00 \%$ & $\$ 82,719$ \\
\hline Kansas & Johnson County & 151280 Counted ( $95 \%)$ & $45 \%$ & 133,907 & $47.90 \%$ & $-2.90 \%$ & $4.90 \%$ & $79.40 \%$ & & $5.40 \%$ & $\$ 81$ \\
\hline Kentucky & Oldham County & 22,654 & $60 \%$ & 20,469 & $62.30 \%$ & $-2.30 \%$ & $4.40 \%$ & $88.20 \%$ & 4.0 & $1.70 \%$ & $\$ 92$ \\
\hline Loussianna & Ascension Parish & 40,687 & $65 \%$ & 36,135 & $66.10 \%$ & $-1.10 \%$ & $24.00 \%$ & $67.50 \%$ & $6.00 \%$ & $1.40 \%$ & $\$ 74,748$ \\
\hline Main & Cumberland County & 59,491 & $31 \%$ & 57,697 & $33.70 \%$ & $-2.70 \%$ & $3.20 \%$ & $10 \%$ & & $2.40 \%$ & \\
\hline Maryland & Howard County & & $27 \%$ & 44,792 & & & & $0 \%$ & & $0 \%$ & 76 \\
\hline Massachusetts & Norfolk County & 123,389 & $32 \%$ & 119,171 & $33.30 \%$ & $-1.30 \%$ & $8.00 \%$ & $73.80 \%$ & $5.00 \%$ & $12.00 \%$ & $\$ 95,668$ \\
\hline Michigan & Livingston County & 76,982 & $61 \%$ & 65,665 & $62.20 \%$ & $-1.20 \%$ & $0.70 \%$ & $94.10 \%$ & $2.60 \%$ & $1.00 \%$ & $\$ 78$ \\
\hline Minnisota & Scott County & 45,871 - & $52 \%$ & & & & & & & $6.40 \%$ & \\
\hline Mississippi & Madison County & 31,0 & $55 \%$ & 25,607 & $56.80 \%$ & & & $10 \%$ & & $2.80 \%$ & \\
\hline Missouri & St. Charles County & 128,193 & $58 \%$ & 120,899 & $60.60 \%$ & $-2.60 \%$ & $5.30 \%$ & $86.60 \%$ & $3.40 \%$ & $2.80 \%$ & $\$ 78,380$ \\
\hline Montana & Richland County & 4,800 & $.00 \%$ & 3,885 & $0 \%$ & $2.40 \%$ & $0 \%$ & $0 \%$ & & $0.50 \%$ & \\
\hline Nabraska & Sarpy County & 51,518 Counted $(95 \%)$ & $54 \%$ & & & & & $0 \%$ & & $2.70 \%$ & \\
\hline Nevada & Elko County & 16,741 Counted (95\%) & $76 \%$ & 13,542 & $73.00 \%$ & $3 \%$ & $1.30 \%$ & $66.50 \%$ & $24.70 \%$ & $1.20 \%$ & $\$ 76,178$ \\
\hline New Hampshire & Rockingham County & 95,585 & $49 \%$ & 90,447 & $50.50 \%$ & $50 \%$ & $2.50 \%$ & $87.90 \%$ & $7.40 \%$ & $1.00 \%$ & \\
\hline New Jersey & Hunterdon County & 43.153 Counted $(95 \%)$ & $51 \%$ & & & & & & & $4.40 \%$ & 69 \\
\hline New Mexico & Los Alamos County & 4,278 Counted $(95 \%)$ & $35 \%$ & 3,329 & & $3.90 \%$ & $1.40 \%$ & $71.20 \%$ & 18. & $6.60 \%$ & 90 \\
\hline New York & Nassau County & 324,858 Counted $(95 \%)$ & $45 \%$ & 75,479 & $45.90 \%$ & $-0.90 \%$ & $13.10 \%$ & $58.50 \%$ & $17.50 \%$ & $10.90 \%$ & 744 \\
\hline North Carolina & Wake County & 226,167 & $36 \%$ & & & & & $0 \%$ & & $7.70 \%$ & \\
\hline North Dakota & Williams County & 11,739 & $\%$ & & & & & $0 \%$ & & $0.90 \%$ & \\
\hline Ohio & Delaware County & 66,365 Counted $(95 \%)$ & $53 \%$ & 55,660 & $55.60 \%$ & $-2.60 \%$ & $\%$ & $0 \%$ & 2.8 & $7.60 \%$ & 229 \\
\hline Oklahoma & Canadian County & 43,350 & $70 \%$ & 39,969 & $72.30 \%$ & $-2.30 \%$ & $0 \%$ & $10 \%$ & 9.8 & $3.30 \%$ & $\$ 6 \$$ \\
\hline Oregon & Washington County & & $31 \%$ & 75,903 & $32.70 \%$ & & $2.50 \%$ & $64.60 \%$ & $17.10 \%$ & $11.70 \%$ & $\$ 74$ \\
\hline Pennsylvania & Chester County & 127.693 Counted $(95 \%)$ & $41 \%$ & 115,582 & $43.30 \%$ & $-2.30 \%$ & & $78.80 \%$ & $7.60 \%$ & $6.10 \%$ & $\$ 9$ \\
\hline Rhode Island & Washington County & 29,818 & $40 \%$ & 27,074 & $\%$ & $-2.10 \%$ & $1.50 \%$ & $0 \%$ & 3.4 & $2.00 \%$ & $\$ 77$ \\
\hline South Carolina & Beaufort County & 53,194 & $54 \%$ & 39,986 & $54.90 \%$ & & $17.90 \%$ & $68.50 \%$ & $11.10 \%$ & $1.50 \%$ & $\$ 60$ \\
\hline South Dakota & Lincoln County & 19,617 & $61 \%$ & 15,499 & $61.40 \%$ & $-0.40 \%$ & $1.80 \%$ & $92.20 \%$ & $2.40 \%$ & $1.50 \%$ & $\$ 81,849$ \\
\hline Tennessee & Williamson County & 86,469 Counted (95\%) & $62 \%$ & 68,160 & $65.10 \%$ & $-3.10 \%$ & $4.50 \%$ & $83.80 \%$ & $4.90 \%$ & $5.20 \%$ & $\$ 103,543$ \\
\hline Texas & Fort Bend County & 157,595 Counted $(95 \%)$ & $44 \%$ & 117,212 & $45.00 \%$ & $-1 \%$ & & $31.90 \%$ & $24.90 \%$ & $20.90 \%$ & $\$ 93,645$ \\
\hline Utah & Summit County & 10,252 Counted $(95 \%)$ & $39 \%$ & 7,160 & $35.60 \%$ & $4.40 \%$ & $1.20 \%$ & $84.00 \%$ & $11.50 \%$ & $1.90 \%$ & $\$ 94,952$ \\
\hline Vermont & Chittenden County & 21017 Counted $(95 \%)$ & $22 \%$ & 18,298 & $23.70 \%$ & $-1.70 \%$ & $2.50 \%$ & $88.30 \%$ & $2.50 \%$ & $4.60 \%$ & $\$ 66,906$ \\
\hline Virginia & Loudoun County & 82,088 Counted $(95 \%)$ & $37 \%$ & 69,633 & $38.60 \%$ & $-1.60 \%$ & $8.10 \%$ & $54.80 \%$ & $13.90 \%$ & $20.30 \%$ & $\$ 129,588$ \\
\hline Washington & King County & 268,684 & $22 \%$ & 197,781 & $21.70 \%$ & $-0.30 \%$ & $7.00 \%$ & $58.10 \%$ & $9.90 \%$ & $19.70 \%$ & $\$ 83,571$ \\
\hline East Virginia & Jefferson County & 15,033 Counted $(95 \%)$ & $54 \%$ & 13,144 & $54.80 \%$ & $-0.80 \%$ & $6.40 \%$ & $83.20 \%$ & $6.30 \%$ & $1.60 \%$ & $\$ 72,526$ \\
\hline Wisconsin & Waukesha County & 159,649 & $60 \%$ & 145,519 & $61.60 \%$ & $-1.60 \%$ & $1.80 \%$ & $88.00 \%$ & $4.90 \%$ & $3.80 \%$ & $\$ 81,140$ \\
\hline Wyoming & Campbell County & 16,975 & $87 \%$ & 15,778 & $88.00 \%$ & $-1 \%$ & $0.70 \%$ & $86.90 \%$ & $0.80 \%$ & $8.90 \%$ & $\$ 80,178$ \\
\hline
\end{tabular}

\section{Analyzing the Average Districts of America}

In most of the average districts analyzed, Trump increased the total number of voters between the 2016 and 2020 elections. [In Hampshire County, Mass., the count was just short of his 2016 numbers, and could reach them when it becomes final.] Trump increased his support in 33 of the counties. In one county it was a draw, and in 15 counties there was a decrease in the percentage of the vote received by Trump compared to 2016. 
Overall, Trump saw a decrease in the support for him in 30.61\% of the average districts across the US between 2016 and 2020; at the same time, he experienced an increase in the support for him in $67.34 \%$ of the sampled average districts across America.

The interesting data point regarding the average districts in America is that in five of the top six districts (measured by earning ability), Trump saw a decrease in the percentage of votes he received, while only one showed an increase in support towards the incumbent president. This shows that as one approaches the $\$ 70,000$ annual income benchmark, the data resembles that of the rich counties more and more.

\begin{tabular}{|c|c|c|c|c|c|c|c|}
\hline State & County & $\begin{array}{l}2016 \\
\text { Votes }\end{array}$ & $\begin{array}{l}2016 \\
\text { Percentage }\end{array}$ & $\begin{array}{l}2020 \\
\text { Votes }\end{array}$ & $\begin{array}{l}2020 \\
\text { Percentage }\end{array}$ & Change & $\begin{array}{l}\text { Avg. } \\
\text { Income }\end{array}$ \\
\hline Virginia & Roanoke & 34,268 & $60 \%$ & 30,857 & $61.50 \%$ & $-1.50 \%$ & $\$ 68,734$ \\
\hline $\begin{array}{l}\text { New } \\
\text { Hampshire }\end{array}$ & Strafford & 30,489 & $42 \%$ & 29,072 & $42.80 \%$ & $-0.80 \%$ & $\$ 69,919$ \\
\hline Connecticut & Hartford & $\begin{array}{l}\frac{159,370}{\text { counted }} \\
(97 \%)\end{array}$ & $36 \%$ & 147,912 & $37.10 \%$ & $-1.10 \%$ & $\$ 73,037$ \\
\hline Massachusetts & Hampshire & $\begin{array}{l}\frac{21,807}{\text { counted }} \\
\frac{(95 \%)}{(50)}\end{array}$ & $26.8 \%$ & 22,089 & $26.00 \%$ & $-0.80 \%$ & $\$ 74,456$ \\
\hline Hawaii & Kauai & $\begin{array}{l}\frac{11,582}{\text { counted }} \\
(92 \%)\end{array}$ & $35 \%$ & 7,574 & $28.80 \%$ & $6.20 \%$ & $\$ 73,981$ \\
\hline Maryland & Baltimore & $\begin{array}{l}\frac{146,172}{\text { counted }} \\
(95 \%)\end{array}$ & $36 \%$ & 131,009 & $39.10 \%$ & $-3.10 \%$ & $\$ 75,836$ \\
\hline
\end{tabular}


In four of the fifteen districts showing a decrease in overall support, there was also a flip from favoring the Republican Party's candidate to that of the Democratic Party. These were seen in Indiana (Tippecanoe County), where despite the state remaining Republican, Trump dropped 1.6\% of the vote; Maine, which remained blue also in 2020 but saw the President lose $0.1 \%$ of the vote in Kennebec County — enough to flip the county itself from red to blue; Oregon (Marion County) saw Trump lose 1.0\% compared to 2016, and the district flipped from red to blue; and Rhode Island (Kent County) flipped after Trump received $1.8 \%$ less of the vote.

\begin{tabular}{|c|c|c|c|c|c|c|c|c|c|c|c|c|}
\hline Siste & Distict & 2020 Votes for Trump 2 & 2020 Percentiz2011. & tes fortron20 & MG Percen P. & centrage of & can-American ?withe & & eAmerican & Asinn $\%$ & Avg. heor & niy Avg. hoone-SSale \\
\hline Hawai & Kovia County & 11.582 Counted (OS5/) & $35 \%$ & 7,574 & $28.00 \%$ & $620 \%$ & $0.70 \%$ & $33.00 \%$ & $9.10 \%$ & $31.0 \% \%$ & $11.40 \% 8973,989$ & $\$ 74,223$ \\
\hline bato & Bingham County & 15,265 & $70 \%$ & 10,907 & $65.00 \%$ & 1050\%\% & $0.60 \%$ & $73.00 \%$ & $2 \%$ & $1.00 \%$ & $17.09 \% \$ \$ \$ 0,941$ & $\$ 50,985$ \\
\hline llinos & Trzevel County & 42,194 Counted (55\%) & $62 \%$ & 386020 & $61.0 \% \%$ & $1 \%$ & $0.00 \%$ & $9370 \%$ & $0.30 \%$ & $0.00 \%$ & $250 \% 8500773$ & 981229 \\
\hline addena & Tippecanoe county & 3458 Conited (155) & $48 \%$ & 30,711 & $4900 \%$ & $.100 \%$ & $5.0 \%$ & $7400 \%$ & $0.2 \%$ & $880 \%$ & $8.70 \% 582269$ & $\$ 52182$ \\
\hline bwa & Illonree County & 2975 Coniter (95\%) & $73 \%$ & 26035 & $68.50 \%$ & $450 \%$ & $0.80 \%$ & $94.00 \%$ & & $0 \%$ & $270 \% 856,544$ & 956,50 \\
\hline Kansas & Thomas County & 3106 & $82 \%$ & 2.832 & $81.30 \%$ & $0.70 \%$ & $1.20 \%$ & $88.00 \%$ & $1.10 \%$ & $0.80 \%$ & $7.50 \% 855,345$ & 355,477 \\
\hline Kentudy & Ilongoneney County & 8993 & $70 \%$ & 7,856 & $680.00 \%$ & $1.40 \%$ & $2.0 \% \%$ & $9200 \%$ & $0.10 \%$ & $0.50 \%$ & $200 \% 8866020$ & $\$ 46,535$ \\
\hline Loussimma & Pointe Counee Parish & 7,503 & $71 \%$ & 6,789 & $57,70 \%$ & 1330\%\% & $35.50 \%$ & $60.40 \%$ & & $0.30 \%$ & $200 \% 8860003$ & $\$ 46710$ \\
\hline Vhain & Kemendere County & 34,151 Conited (95\%) & $48 \%$ & 31,53 & $48.10 \%$ & $.010 \%$ & $0.00 \%$ & $94.0 \% \%$ & $0.00 \%$ & $1 \%$ & $1.70 \% 55252,48$ & $\$ 53,024$ \\
\hline Varyand & Ballinore County & 146,172 Counted (948) & $30 \%$ & 131,099 & $399.10 \%$ & $.310 \%$ & $30.00 \%$ & $55.00 \%$ & $0.10 \%$ & $6.30 \%$ & 58008975880 & $\$ 88916$ \\
\hline |lassactusestls & Harnosire Couny & 21,807 Counted $(92 \%)$ & $20 \%$ & 22089 & $26.00 \%$ & $.000 \%$ & $3.40 \%$ & $83.30 \%$ & $0.30 \%$ & $5.70 \%$ & $5.90 \% 874,450$ & $\$ 4,167$ \\
\hline lichigann & St. losen County & 18,127 & $65 \%$ & 14886 & $62600 \%$ & $2.00 \%$ & $5.20 \%$ & $86.30 \%$ & $1.20 \%$ & $0.80 \%$ & $4.10 \% 85262689$ & $\$ 526068$ \\
\hline Ilinisovis & Steet Couny & 12655 Conited (155\%) & $60 \%$ & 11,198 & $58.00 \%$ & $120 \%$ & $3.50 \%$ & $85.00 \%$ & $0.50 \%$ & $1.10 \%$ & $8.20 \% 8565,323$ & 965699 \\
\hline |lissssspipi & Greene County & 4,794 & $82 \%$ & 4,309 & $80.90 \%$ & $1.10 \%$ & $25.00 \%$ & $7220 \%$ & & $0.20 \%$ & $1.20 \% \$ 82,022$ & $\$ 42009$ \\
\hline Ilissouri & Daviess County & 3,077 & $79 \%$ & 2,763 & $74.00 \%$ & $40 \% \%$ & $0.00 \%$ & $960.0 \% \%$ & $0.50 \%$ & $0.30 \%$ & $1.40 \% 8551.255$ & $\$ 51,542$ \\
\hline Vortange & Treasure County & 373 & $81 \%$ & 350 & $79.20 \%$ & $1.00 \%$ & & $90.20 \%$ & $3.00 \%$ & $1.0 \% \%$ & $420 \% 850,774$ & $\$ 508001$ \\
\hline Nobassla & Filloroe County & 2359 conter (195\%) & $75 \%$ & 2,100 & $7200 \%$ & $2.0 \%$ & $1.00 \%$ & $93.30 \%$ & & $0.70 \%$ & $3.90 \% 8566097$ & 956,675 \\
\hline Nerads & Linconn County & 2067 Conter (95\%) & $84 \%$ & 1,671 & $78.00 \%$ & $600 \%$ & $3.30 \%$ & $84.50 \%$ & $1.00 \%$ & $0.70 \%$ & $7800 \% 8565054$ & 355,644 \\
\hline New Hemsoshice & e Straflitor County & 30,499 & $42 \%$ & 20,072 & $4200 \%$ & $.000 \%$ & $1.40 \%$ & $90.20 \%$ & & $370 \%$ & $280 \% 8999919$ & 871,305 \\
\hline New Jersey & Waren County & 34.799 Counted (S5\%) & $57 \%$ & 293993 & $60.70 \%$ & $.370 \%$ & $5.70 \%$ & $80.40 \%$ & $0.10 \%$ & $200 \%$ & $10.20 \% 877,571$ & 876,475 \\
\hline New llexico & San Juan County & 32874 Counted (55\%) & $63 \%$ & 27879 & $60.00 \%$ & $20.0 \%$ & $0.80 \%$ & $37.50 \%$ & $41.00 \%$ & $0.10 \%$ & $20.00 \% \$ 46,578$ & $\$ 66718$ \\
\hline New York & Ontraric County & 826 conited & $54 \%$ & 24,343 & $51.10 \%$ & $200 \%$ & $280 \%$ & $89.50 \%$ & $0.00 \%$ & $1.00 \%$ & $5.10 \% 852930$ & 982765 \\
\hline Noth Croving & Person County & 13,184 & $60 \%$ & 11,16 & $57.00 \%$ & $200 \%$ & $26800 \%$ & $66.30 \%$ & $0.90 \%$ & $0.0 \% \%$ & $4.50 \% 850,449$ & $\$ 50,320$ \\
\hline Noth Dadolata & Richlard County & 5,072 & $65 \%$ & 4,759 & $63.00 \%$ & $120 \%$ & $1.0 \%$ & $90.50 \%$ & $3.10 \%$ & $0.00 \%$ & $3.00 \% 868,174$ & 961,285 \\
\hline Ohio & Stark County & 111,098 Counted (926) & $58 \%$ & 963,35 & $56.40 \%$ & $1.00 \%$ & $800 \%$ & $80.20 \%$ & $0.30 \%$ & $0.30 \%$ & $220 \% 852310$ & $\$ 52,07$ \\
\hline Oldatorna & Cosiste County & 8,000 & $75 \%$ & 78,818 & $7420 \%$ & $0.00 \%$ & $3.30 \%$ & $67.50 \%$ & $8.00 \%$ & $1.30 \%$ & $1890 \% 8989577$ & $\$ 99767$ \\
\hline Orepon & Mrom County & 79,000 & $48 \%$ & 54,336 & $49.00 \%$ & $.1 \%$ & $1.00 \%$ & $6470 \%$ & $200 \%$ & $250 \%$ & $27: 20 \%, 856,48$ & S56,119 \\
\hline Pensylyonita & Snyder County & 139833 Counted (55\%) & $733 \%$ & 117,70 & $71.70 \%$ & $1.30 \%$ & $1.00 \%$ & $94.00 \%$ & $0.20 \%$ & $0.70 \%$ & $220 \% 856099$ & $\$ 56,951$ \\
\hline hioded sand & KentCounty & 41,999 & $40 \%$ & 38,41 & $47.00 \%$ & $.100 \%$ & $250 \%$ & $87.0 \% \%$ & $0.50 \%$ & $200 \%$ & $5.70 \% 8980089$ & 981,043 \\
\hline South Croving & Pickens County & 42,007 & $75 \%$ & 36096 & $73.00 \%$ & $1.0 \%$ & $20.0 \% \%$ & $85.20 \%$ & $0.00 \%$ & $200 \%$ & $390 \% 8887994$ & $\$ 48781$ \\
\hline South Dadola & Avvor Count, SO & 1,052 & $75 \%$ & 974 & $6920 \% \%$ & $500 \%$ & $230 \%$ & $87.00 \%$ & $200 \%$ & $0.70 \%$ & $7.20 \% 554434$ & $\$ 54,126$ \\
\hline Tenessese & Humphreys county & 6.116 Contred (95\%) & $74 \%$ & 4928 & $690.0 \%$ & $5 \%$ & $200 \%$ & $9230 \%$ & $0.00 \%$ & $0.50 \%$ & $200 \% 8980.560$ & $\$ 88708$ \\
\hline Texas & Shemman County & 8886 Conned $73 \%$ ) & $89 \%$ & 807 & $86.50 \%$ & $250 \%$ & $1.00 \%$ & $5200 \%$ & $130 \%$ & $0.00 \%$ & $44.20 \%: 557,052$ & $\$ 57,051$ \\
\hline Wian & Jusc Couny & 55987 Conted (1956) & $87 \%$ & 2,759 & $67,0 \% \%$ & $20 \%$ & $0.00 \%$ & $91.10 \%$ & $1.20 \%$ & $0.0 \% \%$ & $580 \% 8655,79$ & 966,225 \\
\hline Vermont & Winssoc County & 9971 Conter $197 \%$ & $30 \%$ & 8004 & $30.90 \%$ & $.090 \%$ & $1.00 \%$ & $94.30 \%$ & $0.30 \%$ & $1.00 \%$ & $1.80 \%: 557,438$ & $\$ 57,808$ \\
\hline Virghina & Porande County & 34,288 & $00 \%$ & 30,857 & $61.50 \%$ & $.150 \%$ & $6.00 \%$ & $85.20 \%$ & & $3.00 \%$ & $330 \% 6888,734$ & 9887766 \\
\hline Waschington & Bsanc County & 226988 & $43 \%$ & 18.259 & $430.0 \%$ & Wh & $320 \%$ & $78.50 \%$ & $1.0 \%$ & $5.10 \%$ & $8.20 \% 8656987$ & 986,174 \\
\hline Eass Virgning & Hanmsirie County & 8,033 & $80 \%$ & 6,646 & $77.70 \%$ & $230 \%$ & $1.40 \%$ & $95.00 \%$ & $0.20 \%$ & $0.30 \%$ & $1.50 \% \$ 84,442$ & $\$ 44,061$ \\
\hline Wiscomin & Linon County & 10,017 & $61 \%$ & 8400 & $5770 \%$ & $300 \%$ & $0.09 \%$ & $9520 \%$ & $0.00 \%$ & $0.00 \%$ & $1.70 \% 8560645$ & 586759 \\
\hline Wyorino & Carton County & 5,014 & $75 \%$ & 4,409 & $71.10 \%$ & $300 \%$ & $1.20 \%$ & $76.00 \%$ & $1.00 \%$ & $1.00 \%$ & $185.50 \% 8801,773$ & 9090938 \\
\hline
\end{tabular}

Overall, President Trump saw an average increase of 2.09\% in the number of voters supporting him in the average districts during 2020 when compared to the results from 2016. 


\section{Analyzing the Poorest Districts in America}

President Trump in the majority of the poor districts showed an increase in support for him in 40 of the 49 sample districts between 2016 and 2020. In two districts there was a draw, and in six, he saw a decrease in support. The state of California had yet to count all the votes, and was omitted from this analysis.

Overall, in $12.5 \%$ of America's poorest districts, Trump saw a decrease in support, compared to an increase in $83.33 \%$ of the districts sampled. The single state without change equals $4.16 \%$ of the data.

Interestingly, none of the poor districts saw a change of hands, and all went to Trumpwithout a single Biden victory.

In total, Trump had an average increase of $3.16 \%$ in the number of voters supporting him in the 2020 elections across the poorest districts in the US compared to his results in 2016.

\begin{tabular}{|c|c|c|c|c|c|c|c|c|c|c|c|}
\hline State & District & 2020 Votes for Trump & 2 & 16 Vote & $\mathrm{rc}$ & Perc & African-Al & White $\%$ & ve $A m$ & Hispanic & Avg. \\
\hline Alabama & Sumter & 1598 & $25.50 \%$ & 1,581 & $24.70 \%$ & $0.80 \%$ & $75 \%$ & $24.20 \%$ & $0.00 \%$ & $0.60 \%$ & $\$ 21,663$ \\
\hline Arizona & Apache County & 11442 & $32.50 \%$ & 8240 & $30 \%$ & $2.50 \%$ & $0.72 \%$ & $18.30 \%$ & $73.10 \%$ & $4.56 \%$ & $\$ 32,360$ \\
\hline Arkansas & Phillips County & 2417 & $38.70 \%$ & 2446 & $35 \%$ & $3.70 \%$ & $59.40 \%$ & $39.25 \%$ & $0.17 \%$ & $1.44 \%$ & $\$ 26,652$ \\
\hline California & Lake County & 3.955 Counted $(42 \%)$ & $36 \%$ & 10,599 & $43 \%$ & & $1.90 \%$ & $80.50 \%$ & $1.10 \%$ & & $\$ 40,446$ \\
\hline Colorado & Otero County & 5756 Counted $(95 \%)$ & $60 \%$ & 2988 & $59.30 \%$ & $0.70 \%$ & $1.40 \%$ & $53.80 \%$ & & $41.70 \%$ & $\$ 35,051$ \\
\hline Coneticut & Windham County & 29,141 & $52 \%$ & 25,738 & $50.80 \%$ & $1.20 \%$ & & $83.10 \%$ & & $11.00 \%$ & $\$ 62,553$ \\
\hline Delaware & Kent County & 41,009 & $47 \%$ & 36,989 & $49.80 \%$ & $-2.80 \%$ & $24.50 \%$ & $62.20 \%$ & & $4.16 \%$ & $\$ 57,647$ \\
\hline Florida & Madison County & 5576 & $59 \%$ & 4851 & $57 \%$ & $2 \%$ & $40.30 \%$ & $57.49 \%$ & $0.32 \%$ & $3.20 \%$ & $\$ 31,816$ \\
\hline Georgia & Telfair County & 2825 & $65 \%$ & 2,449 & $64.50 \%$ & $0.50 \%$ & $36.50 \%$ & $57.00 \%$ & & $12.00 \%$ & $\$ 28,044$ \\
\hline Hawaii & Hawaii County & 26851 & $31 \%$ & 17,209 & $27.10 \%$ & $3.90 \%$ & $0.70 \%$ & $34.50 \%$ & & $11.80 \%$ & $\$ 56,395$ \\
\hline Idaho & Madison County & 13559 & $79 \%$ & 8,941 & $57 \%$ & $22 \%$ & $0.24 \%$ & $95.50 \%$ & $0.33 \%$ & $3.92 \%$ & $\$ 33,620$ \\
\hline Illinois & Alexander County & 1486 Counted $(87 \%)$ & $57 \%$ & 1,496 & $53 \%$ & $4 \%$ & $35.40 \%$ & $60.90 \%$ & $0.30 \%$ & $1.90 \%$ & $\$ 31,014$ \\
\hline Indiana & Crawford County & 3499 & $70 \%$ & 3,013 & $65.60 \%$ & $4.40 \%$ & & $96.30 \%$ & & $1.40 \%$ & 0,067 \\
\hline lowa & Appanoose County & $\underline{4512 \text { Counted }}$ & $69 \%$ & 4,031 & $66.10 \%$ & $2.90 \%$ & $0.90 \%$ & $96.40 \%$ & & $2.20 \%$ & $\$ 40,377$ \\
\hline Kansas & Crawford County & 9752 & $60 \%$ & 4 & $58.30 \%$ & $1.70 \%$ & $1.83 \%$ & $93.29 \%$ & $0.94 \%$ & & 017 \\
\hline Kentucky & McCreary County & 5664 Counter & $88 \%$ & 20,774 & $66.40 \%$ & $21.60 \%$ & $0.63 \%$ & $97.99 \%$ & $0.42 \%$ & & 264 \\
\hline Loussianna & laiborne Parish & 5790 Counted & $57 \%$ & 3,585 & $55.80 \%$ & $1.20 \%$ & $47.37 \%$ & $51.80 \%$ & $4 \%$ & $0.76 \%$ & $\$ 26,877$ \\
\hline Main & Piscataquis County & 5703 Counted ( $89 \%)$ & $62 \%$ & 5,403 & $59.10 \%$ & $2.90 \%$ & $0.21 \%$ & $97.84 \%$ & $0.52 \%$ & & $\$ 38,797$ \\
\hline Maryland & Illegany County & 20886 Counted ( $89 \%)$ & $69 \%$ & 20,025 & $72.00 \%$ & -3 & $5.35 \%$ & $93.02 \%$ & $0.15 \%$ & $0.76 \%$ & $\$ 42,771$ \\
\hline Massachusetts & Hampden County & 84,231 Counted $(92 \%)$ & $41 \%$ & 78,230 & $39.10 \%$ & $1.90 \%$ & $9.00 \%$ & $76.50 \%$ & & $20.9 \%$ & $\$ 52,205$ \\
\hline Michigan & Lake County & 3946 & $62 \%$ & 3,159 & $59.30 \%$ & $2.70 \%$ & $11.17 \%$ & $84.66 \%$ & $1.01 \%$ & $1.69 \%$ & $\$ 32,309$ \\
\hline Minnisota & Mahnomen County & 43 & $50 \%$ & 991 & $47.80 \%$ & $2.20 \%$ & $0.13 \%$ & $45.80 \%$ & $39.00 \%$ & & $\$ 42,439$ \\
\hline Mississippi & Holmes County & 1196 & $18 \%$ & 1,151 & $16.30 \%$ & $1.70 \%$ & $83.70 \%$ & $15.60 \%$ & & $0.15 \%$ & $\$ 20,330$ \\
\hline Missouri & Shannon County & 3164 Counted ( $95 \%$ ) & $81 \%$ & 2,966 & $76.00 \%$ & $5 \%$ & $0.50 \%$ & $95.20 \%$ & $1.40 \%$ & $2 \%$ & $\$ 31,202$ \\
\hline Montana & ine County & 1469 & $47 \%$ & 1,259 & $47.60 \%$ & $-0.60 \%$ & & $45 \%$ & 49. & $30 \%$ & $\$ 35,506$ \\
\hline Nabraska & ridan County & 2292 Count & $86 \%$ & 2,192 & $85.50 \%$ & $\%$ & $0.08 \%$ & $88.11 \%$ & $9.23 \%$ & & 209 \\
\hline Nevada & re County & 17.528 Counted $(95 \%)$ & $69 \%$ & 0 & $00 \%$ & $1 \%$ & $18 \%$ & $90.0 \%$ & & $6 \%$ & 225 \\
\hline New Hampshir & Coos County & 8.617 Coun & $53^{\circ}$ & 1 & $52.00 \%$ & $1 \%$ & $0.91 \%$ & $95.90 \%$ & & $0.91 \%$ & 386 \\
\hline New Jersey & Cumberland County & 28,952 Counted ( $95 \%)$ & $46^{\circ}$ & 24,213 & $45.70 \%$ & $0.30 \%$ & $20.30 \%$ & $47 \%$ & & $27 \%$ & $\$ 50,000$ \\
\hline New Mexico & Quay County & 2634 Counted $(95 \%)$ & $68 \%$ & 2,208 & $61.90 \%$ & $6.10 \%$ & $0.84 \%$ & $82.09 \%$ & $1.27 \%$ & $37.98 \%$ & $\$ 26,663$ \\
\hline New York & onx County & 55849 Counted $74 \%$ & $17 \%$ & 34,424 & $9.60 \%$ & $7.40 \%$ & $35.64 \%$ & $29.87 \%$ & & $48.38 \%$ & $\$ 36,593$ \\
\hline North Carolina & Bertie County & 38 & $39 \%$ & 3,476 & $37.10 \%$ & $1.90 \%$ & $62.34 \%$ & $36.30 \%$ & $0.44 \%$ & $0.99 \%$ & $\$ 31,287$ \\
\hline North Dakota & Rolette County & 1257 & $33 \%$ & 1,210 & $33.00 \%$ & 0 & & $40.40 \%$ & $52.20 \%$ & $0.91 \%$ & $\$ 36,170$ \\
\hline Ohio & dams County & 9870 Counted $(95 \%)$ & $81 \%$ & 8,445 & $76.30 \%$ & $4.70 \%$ & & $96.40 \%$ & & $1.00 \%$ & $\$ 36,320$ \\
\hline Oklahoma & Choctaw County & 4698 & $81 \%$ & 4,202 & $77.50 \%$ & $3.50 \%$ & $10.94 \%$ & $68.55 \%$ & $14.96 \%$ & $1.60 \%$ & 298 \\
\hline Oregon & Iheur County & 187 & $69 \%$ & 7,141 & $71.80 \%$ & $-2.80 \%$ & $1.20 \%$ & $77.50 \%$ & $1.20 \%$ & & 112 \\
\hline Pennsylvania & Forest County & 1864 & $71 \%$ & 1,680 & $70.10 \%$ & $0.90 \%$ & $2.22 \%$ & $95.94 \%$ & $0.40 \%$ & 1.21 & 106 \\
\hline Rhode island & Providence County & 102546 Counted ( $96 \%)$ & $38 \%$ & 0,321 & $37.30 \%$ & $0.70 \%$ & $8.61 \%$ & $60.10 \%$ & & $13.40 \%$ & 30 \\
\hline South Carolina & Allendale County & & $3 \%$ & 788 & $22.00 \%$ & $1 \%$ & $71 \%$ & $.37 \%$ & & $1.61 \%$ & 331 \\
\hline South Dakota & Mellette County & 449 & $3 \%$ & 402 & $58.90 \%$ & $-0.90 \%$ & & $0.50 \%$ & $53.80 \%$ & $5.00 \%$ & $\$ 31,165$ \\
\hline Tennessee & Scott County & 8044 Counted & $88 \%$ & 6,044 & $84.90 \%$ & $3.10 \%$ & & $97.30 \%$ & & $0 \%$ & $\$ 31,875$ \\
\hline Texas & Starr County & 8244 & $47^{\circ}$ & 2,218 & $19.00 \%$ & $28 \%$ & & $0.70 \%$ & & $99.10 \%$ & $\$ 27,133$ \\
\hline Utah & Wayne County & 6) & $76^{\circ}$ & 95 & $68.00 \%$ & $8 \%$ & $0.16 \%$ & $29 \%$ & & & $\$ 42,444$ \\
\hline Vermont & sex County & 3 Counted & 5 & ,506 & $55.70 \%$ & $0.30 \%$ & & $5.40 \%$ & & $1.30 \%$ & $\$ 38,767$ \\
\hline Virginia & & & $84^{\circ}$ & 292 & $79.10 \%$ & $4.90 \%$ & $2.62 \%$ & $96.75 \%$ & & $0.47 \%$ & $\$ 30,828$ \\
\hline Washing & cific County & 6930 & $50^{\circ}$ & 5,338 & $50.00 \%$ & $0.00 \%$ & $0.20 \%$ & $90.54 \%$ & $2.44 \%$ & $5.01 \%$ & $\$ 39,895$ \\
\hline East Virginia & cDowell County & 5148 Counted $(95 \%)$ & $79 \%$ & 4,614 & $74.70 \%$ & $4.30 \%$ & $9.5 \%$ & $89.1 \%$ & & & $\$ 25,595$ \\
\hline Wisconsin & Menominee County & & $18 \%$ & 269 & $21.00 \%$ & $-3 \%$ & $0.07 \%$ & $11.57 \%$ & $\% \%$ & $2.67 \%$ & $\$ 38,080$ \\
\hline Wyoming & Albany County & 8579 & $46 \%$ & 7,601 & $46.30 \%$ & $0.30 \%$ & $2 \%$ & $82.90 \%$ & $1.10 \%$ & $9.40 \%$ & $\$ 45,816$ \\
\hline
\end{tabular}


An important statistic to highlight is that in the poor districts, unlike the average and rich ones, there are districts with an overwhelming number of minority groups (non-white ethnicities and backgrounds). A closer look at those districts with at least one third (33\%) of a minority, shows us the following:

The Hispanic/Latino Vote

Data about the Hispanic/Latino vote might be the most interesting story regarding the elections being decided by race or ethnicity. In the four districts where the Latinos make up over $37 \%$ (and up to $99.1 \%$ ) of the population, Trump's popularity increased. Starr County, in Texas, borders Mexico and is comprised of over $99 \%$ of residents identifying as Latino-Americans. There, Trump's support grew by 19 points from 2016 to 2020, when he received $47 \%$ of the vote.

Also, in the Bronx District of New York, where nearly half the residents identify as Latinos, there was a steady increase in Trump's support, which grew by $7.4 \%$ compared to 2016 .

\begin{tabular}{|l|l|l|l|l|l|l|l|}
\hline State & County & $\begin{array}{l}2016 \\
\text { Votes }\end{array}$ & $\begin{array}{l}2016 \\
\text { Percentage }\end{array}$ & $\begin{array}{l}2020 \\
\text { Votes }\end{array}$ & $\begin{array}{l}2020 \\
\text { Percentage }\end{array}$ & $\begin{array}{l}\text { Change } \\
\text { Ivg. } \\
\text { Income }\end{array}$ \\
\hline Texas & Starr & 2,218 & $19.0 \%$ & 8,244 & $47 \%$ & $28 \%$ & $\$ 27,133$ \\
\hline Cow York & Bronx & 34,424 & $9.6 \%$ & $\begin{array}{l}55,849 \\
\text { Counted } \\
(74 \%\end{array}$ & $17 \%$ & $7.4 \%$ & $\$ 36,593$ \\
\hline $\begin{array}{l}\text { New } \\
\text { Mexico }\end{array}$ & Otero & 2,988 & $59.3 \%$ & $\begin{array}{l}5,756 \\
\text { Counted } \\
(95 \%)\end{array}$ & $60 \%$ & $0.7 \%$ & $\$ 35,051$ \\
\hline
\end{tabular}

\section{The African-American Vote}

In the ten poorest districts across the US, between $35 \%$ and $84 \%$ of the population identifies as African-American. In all ten districts, Trump saw an increase in the support towards him compared to 2016. Of these districts, eight are in red states which voted Trump, while two are in blue states that helped elect Biden. In Bronx County, NY, which we already discussed, is where the steepest increase took place: $84.02 \%$ of the district are either Hispanic or Africa-American.

\begin{tabular}{|l|l|l|l|l|l|l|l|l|}
\hline State & County & $\begin{array}{l}2020 \\
\text { Votes }\end{array}$ & $\begin{array}{l}2020 \\
\text { Percentag } \\
\mathrm{e}\end{array}$ & $\begin{array}{l}2016 \\
\text { Votes }\end{array}$ & $\begin{array}{l}2016 \\
\text { Precentag } \\
\mathrm{e}\end{array}$ & $\begin{array}{l}\text { Chang } \\
\mathrm{e}\end{array}$ & $\begin{array}{l}\% \text { of } \\
\text { African- } \\
\text { American } \\
\text { s }\end{array}$ & $\begin{array}{l}\text { Avg. } \\
\text { Income }\end{array}$ \\
\hline $\begin{array}{l}\text { Mississipp } \\
\mathrm{i}\end{array}$ & Holmes & 1,196 & $18 \%$ & 1,151 & $16.3 \%$ & $1.7 \%$ & $83.7 \%$ & $\begin{array}{l}\$ 20,33 \\
0\end{array}$ \\
\hline Alabama & Sumter & 1,598 & $25.5 \%$ & 1,581 & $24.7 \%$ & $0.8 \%$ & $75 \%$ & $\begin{array}{l}\$ 21,66 \\
3\end{array}$ \\
\hline $\begin{array}{l}\text { S. } \\
\text { Carolina }\end{array}$ & Allendale & 835 & $23 \%$ & 788 & $22.0 \%$ & $1.0 \%$ & $71 \%$ & $\begin{array}{l}\$ 23,33 \\
1\end{array}$ \\
\hline $\begin{array}{l}\text { N. } \\
\text { Carolina }\end{array}$ & Bertie & 3,817 & $39 \%$ & 3,476 & $37.1 \%$ & $1.9 \%$ & $62.34 \%$ & $\begin{array}{l}\$ 31,28 \\
7\end{array}$ \\
\hline $\begin{array}{l}\text { Arkansas } \\
\text { Phillips }\end{array}$ & 2,417 & $38.7 \$$ & 2,446 & $35 \%$ & $3.7 \%$ & $59.4 \%$ & $\begin{array}{l}\$ 26,65 \\
2\end{array}$ \\
\hline $\begin{array}{l}\text { Louisian } \\
\text { a }\end{array}$ & $\begin{array}{l}\text { Claiborne } \\
\text { Parish }\end{array}$ & $\begin{array}{l}5,790 \\
\text { Counte } \\
\mathrm{d} \\
(87 \%)\end{array}$ & $57 \%$ & 3,585 & $55.8 \%$ & $1.2 \%$ & $47.37 \%$ & $\begin{array}{l}\$ 26,88 \\
7\end{array}$ \\
\hline
\end{tabular}




\begin{tabular}{|l|l|l|l|l|l|l|l|l|}
\hline Florida & Madison & 5,576 & $59 \%$ & 4,851 & $57 \%$ & $2.0 \%$ & $40.30 \%$ & $\begin{array}{l}\$ 31,81 \\
6\end{array}$ \\
\hline Georgia & Telfair & 2,825 & $65 \%$ & 2,449 & $64.5 \%$ & $0.5 \%$ & $36.50 \%$ & $\begin{array}{l}\$ 28,04 \\
4\end{array}$ \\
\hline $\begin{array}{l}\text { New } \\
\text { York }\end{array}$ & Bronx & $\begin{array}{l}55,849 \\
\text { Counte } \\
d \\
(74 \%)\end{array}$ & $17 \%$ & $\begin{array}{l}34,42 \\
4\end{array}$ & $9.60 \%$ & $7.4 \%$ & $35.64 \%$ & $\begin{array}{l}\$ 36,59 \\
3\end{array}$ \\
\hline Illinois & $\begin{array}{l}\text { Alexande } \\
\mathrm{r}\end{array}$ & $\begin{array}{l}1,486 \\
\text { counted } \\
(87 \%)\end{array}$ & $57 \%$ & 1,496 & $53 \%$ & $4 \%$ & $35.40 \%$ & $\begin{array}{l}\$ 31,01 \\
4\end{array}$ \\
\hline
\end{tabular}

The Native American Vote

Unlike the previous minorities discussed, the Native American vote saw Trump lose support in districts with over $33 \%$ of the population identifying as members of this group: Three saw a decrease, one saw no change, and two saw an increase.

\begin{tabular}{|l|l|l|l|l|l|l|l|l|}
\hline State & County & $\begin{array}{l}2020 \\
\text { Votes }\end{array}$ & $\begin{array}{l}2020 \\
\text { Percentage }\end{array}$ & $\begin{array}{l}2016 \\
\text { Votes }\end{array}$ & $\begin{array}{l}2016 \\
\text { Precentage }\end{array}$ & $\begin{array}{l}\text { Change } \\
\text { Native- of } \\
\text { Americans }\end{array}$ & $\begin{array}{l}\text { Avg. } \\
\text { Income }\end{array}$ \\
\hline Wisconsin & Menominee & 278 & $18 \%$ & 269 & $21 \%$ & $-3 \%$ & $87.26 \%$ & $\$ 38,080$ \\
\hline Arizona & Apache & 11,442 & $32.5 \%$ & 82,40 & $30 \%$ & $2.5 \%$ & $73.10 \%$ & $\$ 32,360$ \\
\hline S. Dakota & Mellette & 449 & $58 \%$ & 402 & $58.9 \%$ & $-0.9 \%$ & $53.80 \%$ & $\$ 31,165$ \\
\hline N. Dakota & Rolette & 1,257 & $33 \%$ & 1,210 & $33 \%$ & 0 & $52.20 \%$ & $\$ 36,170$ \\
\hline Montana & Blaine & 1,469 & $47 \%$ & 1,259 & $47.6 \%$ & $-0.6 \%$ & $49.50 \%$ & $\$ 35,506$ \\
\hline Minnesota & Mahnomen & 1,143 & $50 \%$ & 991 & $47.8 \%$ & $2.20 \%$ & $39.00 \%$ & $\$ 42,439$ \\
\hline
\end{tabular}




\section{Discussing the Findings}

Or Kulu wrote an interesting article titled "Why Trump Wasn't Weakened Between 2016 and 2020." In it, he brings a quote from a Brookings piece stating: "In 2016, of the more than 3,000 voting districts in the US, only 470 elected Hillary Clinton-yet they accounted for $64 \%$ of the GDP. In 2020, Biden received almost the same number of districts (only seven more) but these accounted for $70 \%$ of the GDP." ${ }^{43}$ Looking at the numbers, the picture is even clearer:

\begin{tabular}{|c|c|c|c|c|}
\hline Year & Candidate & $\begin{array}{l}\text { Counties } \\
\text { won }\end{array}$ & Total votes & $\begin{array}{l}\text { Aggregate } \\
\text { share of } \\
\text { US GDP }\end{array}$ \\
\hline \multirow[t]{2}{*}{2016} & $\begin{array}{l}\text { Hillary } \\
\text { Clinton }\end{array}$ & 472 & $65,853,625$ & $64 \%$ \\
\hline & $\begin{array}{l}\text { Donald } \\
\text { Trump }\end{array}$ & 2,584 & $62,985,106$ & $36 \%$ \\
\hline \multirow[t]{2}{*}{2020} & Joe Biden & 477 & $75,602,458$ & $70 \%$ \\
\hline & $\begin{array}{l}\text { Donald } \\
\text { Trump }\end{array}$ & 2,497 & $71,216,709$ & $29 \%$ \\
\hline
\end{tabular}

Class Breakdown by Districts ${ }^{44}$

This image, after four years, which indicates at the macro level the growing gap between Trump voters in 2016 to Trump voters in 2020, is actually the starting point for a real discussion about the findings in this paper. The data provided in this research, like other information indicating the dichotomy between classes, demonstrates more than anything else how Trump set his offensive strategy to unite various populations around his candidacy. This started in 2016 and continued during his four years in office, bringing with it an overall increase in the number of votes he received in 2020 . The increase in his

${ }^{43}$ Or Kulu, Why Trump Wasn't Weakened From 2016 to 2020, November 17, 2020, Hebrew Source at: http://123kulu.com/uncategorized-he/\%d7\%9e\%d7\%93\%d7\%95\%d7\%a2\%d7\%98\%d7\%a8\%d7\%90\%d7\%9e\%d7\%a4-\%d7\%94\%d7\%aa\%d7\%97\%d7\%96\%d7\%a7-\%d7\%9e-2016$\%$ d7\%9c-2020/ [Accessed at November 25, 2020]

${ }^{44}$ Mark Muro, Eli Byerly Duke, Yang You, and Robert Maxim, Biden-voting counties equal 70\% of America's economy. What does this mean for the nation's political-economic divide?, brookings.edu, NOV 10, 2020. Available at: https://www.brookings.edu/blog/the-avenue/2020/11/09/biden-votingcounties-equal-70-of-americas-economy-what-does-this-mean-for-the-nations-political-economicdivide/, [Accessed at November, 25, 2020]. 
popularity in the lower classes of America appears to be a change in the political base of the Republican Party.

In his book, Kenneth Warren describes how Roosevelt led the revisiting and redefining of the Democratic Party's lines and electorate. "The rise of FDR and the New-Deal coalition in the 1932 elections could mark the most significant realignment in the history of American politics [...] The 1930s allowed the Democratic Party to create a wide base of interests, some with "conflicting agendas, who managed to influence American politics until the late 1960s. The political realignment managed to unite a wide range of ethnic minorities such as the AfricanAmericans, Jews and other ethnicities, alongside labor unions, southerners and progressive elements from the West." 45

Now, the task at the hands of Trump's successor (whoever it may be leading the 2024 campaign for the Republican Party) is to empower the coalition created during his tenurea coalition in which the forgotten or transparent people continue to be part of the day-today attention of the Republican Party. As far as history can teach us, such a processduring which ethnic groups or social classes overwhelmingly flip their support from one party to the other-is a process which takes tens of years and a number of election cycles.

Also, this might be an awakening for the heads of the Democratic Party, who have chosen to take part in the recent trend of 'Identity Politics,' which claim someone must vote for a certain side only because of their racial or ethnic backgrounds and upbringing.

Under the title Identity Politics Fail Again, Tomer Persico and Roie Peled bring an example for this failed approach: "On the eve of the US elections many Democrats were disappointed to see Florida painted Red, not least because of Americans with a Cuban origin voting for Donald Trump. Pulitzer winning journalist Nikole Hannah Jones had an explanation: the Hispanic vote, she tweeted, included 'Black Puerto-Ricans' alongside 'White Cubans.' Thus, in a swipe, the disappointing Cubans were colored as White meaning bad." The two go on and write: "Tagging Cubans as White is nothing more than a clumsy attempt to preserve the identity-centered division through which Hannah-Jones sees the world: White $=$ hegemony and negative at the core; brown $/$ black $=$ depressed and good by nature." 46

\footnotetext{
${ }^{45}$ Kenneth F. Warren, Encyclopedia of U.S. campaigns, elections, and electoral behavior, Los AngelesCA, Sage, 2008. [Translated back from Hebrew]

${ }^{46}$ Tomer Persico, Roie Peled, Lessons from Trump: Identity Politics Fail Again, Haaretz, Hebrew Source, Nov. 24, 2020. Available at: https://www.haaretz.co.il/opinions/.premium-1.9326353 
Whoever thought the 2020 presidential election would center on the issue of race was wrong. This chart explains why one cannot refer to the recent elections as raciallymotivated.

\begin{tabular}{|l|l|l|l|}
\hline \multicolumn{1}{|c|}{ Ethnic Group } & \multicolumn{1}{c|}{2016 Elections } & \multicolumn{1}{c|}{2020 Elections } & Difference in $\%$ \\
\hline Muslims & $8 \%$ & $35 \%$ & $337 \%$ \\
\hline African-American & $8 \%$ & $12 \%$ & $50 \%$ \\
\hline Latino/Hispanic & $28 \%$ & $32 \%$ & $14.29 \%$ \\
\hline Asian-American & $18 \%$ & $30 \%$ & $66.67 \%$ \\
\hline Indian & $16 \%$ & $28 \%$ & $75 \%$ \\
\hline White & $54 \%$ & $58 \%$ & $7.41 \%$ \\
\hline
\end{tabular}

In a world divided by racial or ethnic voting patterns, especially when the discourse was that those hurt by racial slurs and actions would seek revenge at the ballot, such an increase in support for Trump could not happen. True, also in 2016 and also in 2020, Donald Trump only won the votes received from white America. However, other ethnic minorities lent support, with surprising increases across the board—most notably among the Muslim populations.

In this research, which included gathering and sorting data based on social classes in the US, it was possible to see the clear difference in support as one climbed the social ladder, including the changes between 2016 and 2020.

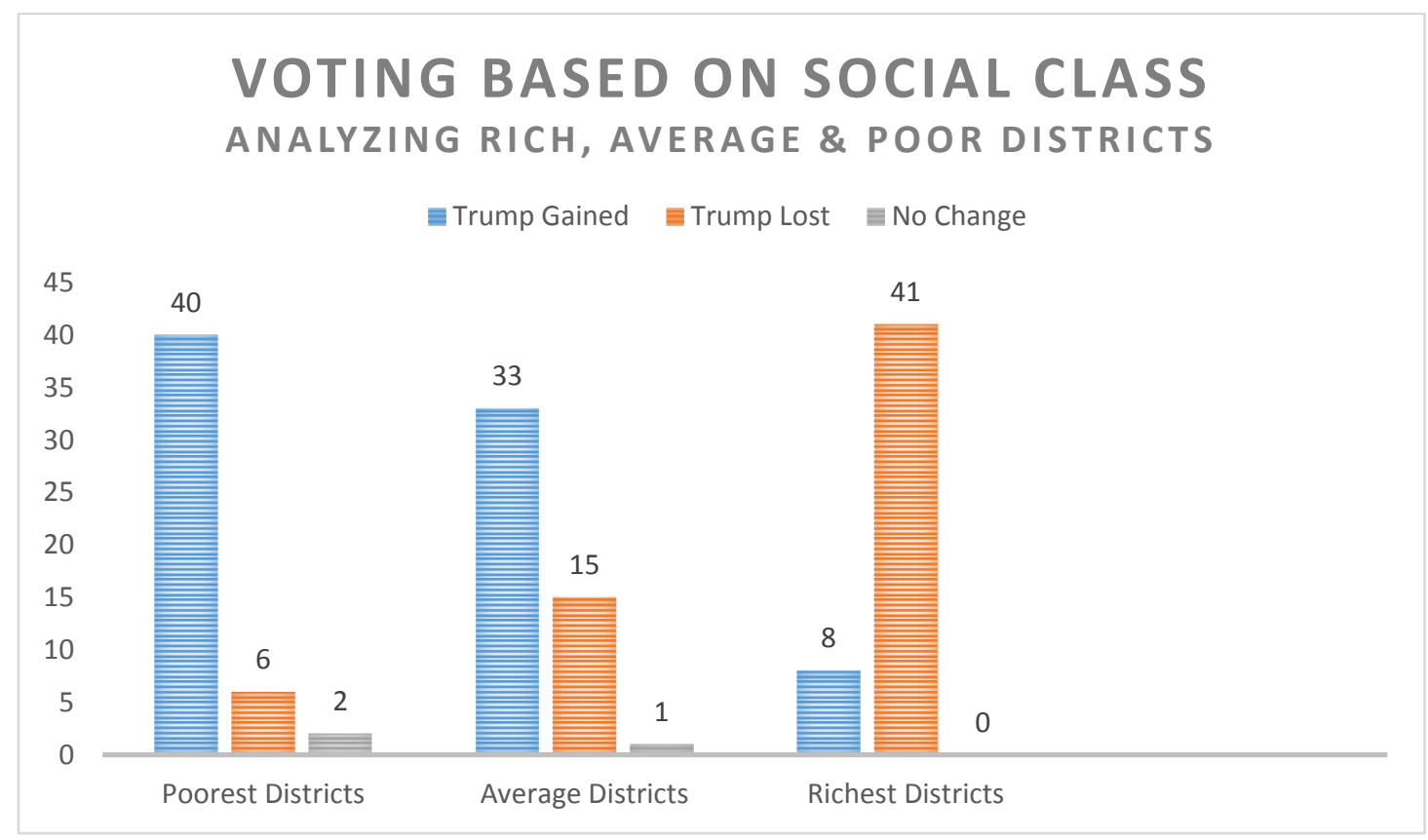

The differences regarding social voting patterns are seen clearly in the accompanying chart, as the rich and poor counties provide mirror images of each other, showing the real dividing line of the American public during the 2020 Presidential Election. 


\section{About the Author}

Kobby Barda heads the "Gal Program" for Political leadership at the Academic Center for Law and Science, Hod-Hasharon, Israel. He is a Ph.D. candidate at the University of Haifa, Israel, and the recipient of the Chaikin Chair for Geostrategy Scholarship. His research focuses on the history of American politics: his dissertation examines the establishment of the Evangelical Lobby for Israel - US relations, while his Masters' thesis was on the forming of AIPAC.

Email: barda@mishpat.ac.il

: Twitter.com/kobbybarda 